\title{
ASSESSMENT AND COMPARISON OF TECHNOLOGY UTILIZATION IN THE TAIWANESE AND AMERICAN INDUSTRIES
}

\author{
Li-Ren Yang/Asst. Professor \\ Dept. of Business Administration \\ Tamkang University \\ Taipei, Taiwan \\ iry@mail.tku.edu.tw
}

\author{
Chung-Fah Huang/Asst. Professor \\ Dept. of Civil Engineering \\ National Kaohsiung University of \\ Applied Sciences, Kaohsiung, Taiwan
}

\author{
James T. O'Connor/Professor \\ Dept. of Civil Engineering \\ University of Texas at Austin \\ Austin, TX 78712, USA
}

\begin{abstract}
The purpose of this study was to investigate the extent to which integration/automation technologies are being used in executing projects in the Taiwanese and American industries and to quantify the similarity and difference in technology usage in the two areas. This was accomplished by two industry-wide surveys and analysis of 209 American projects and 98 Taiwanese projects. Descriptive statistics were developed to determine project-, phase-, and work function-level technology usage. Additionally, hypothesis testing was performed to identify the difference in technology usage between the Taiwanese and American industries. Findings from this study help explain the difference of project stakeholders' interest in introducing integration/automation technologies in the two different geographic regions.
\end{abstract}

Keywords: Technology, automation, integration, project, industry

\section{INTRODUCTION}

This paper presents project technology usage findings from assessment of the levels of technology employed on 68 different common project work functions. The American data was collected on a total 209 completed projects from across the nation between October 1998 and August 1999. The Taiwanese data was collected on a total 98 completed projects between October 2004 and June 2005.

The main objectives of this research are: 1) to investigate the extent to which integration/ automation (IA) technologies are being used in executing projects in the Taiwanese and American industries and 2) to quantify the difference of project stakeholders' interest in introducing integration/automation technologies across national boundaries. Integration is defined as the sharing of information between project participants or melding of information sourced from separate systems. Automation is defined as the use of an electronic or computerized tool by a human being to manipulate data or produce a product.

Technology usage metrics are based on 68 common project work functions. To assess the degree of technology used in executing each work function, technology utilization was divided into three levels: Level 1, Level 2, or Level 3. Each level of technology utilization in executing work functions is defined as follows:

- $\quad$ Level 1 - No electronic tools or only the most common electronic tools are used.

- Level 2 - Uncommon electronic tools play key roles in executing the work function, but human workers still dominate.

- Level 3 - While human workers still participate, fully- or nearly fully- automated systems dominate.

Project technology usage findings are presented and analyzed for the Taiwanese and American industries. In addition, project technology findings are presented by project phase and selected work functions. Research hypotheses were analyzed to examine the difference in technology usage between the Taiwanese and American industries. Technology usage metrics analyzed include those at the project level, at the phase level, at the work function level, and those for task automation (TA) and integration link (IL) work functions.

\section{RESEARCH METHODOLOGY}

Salient aspects of the study methodology are briefly reviewed here:

- The primary statistic computed and analyzed is the integration/automation (IA) technology use index, which is computed on a 0 to 10 point scale.

- In computing both phase- and project-level IA indices, steps were taken to ensure that data representativeness was not threatened by missing data [1].

- For the purpose of this study, a project's life cycle is structured in six phases: Front-End (Phase 1), Design (Phase 2), Procurement (Phase 3), Construction Management (Phase 4), Construction Execution (Phase 5), and Operations/Maintenance (Phase 6).

- In computing phase-level indices, each work function is weighted equally [1].

- In computing project-level indices, each work function is weighted equally.

- An independent-samples $t$ test was conducted to determine whether these data provide evidence for a significant difference in project technology usage between the Taiwanese and American industries. The null hypothesis was that the IA index mean for projects in the Taiwanese industry equals the IA index mean for projects in the U.S industry. The alternative hypothesis stated that the means of the 
two independent groups are not equal. The significance level for statistical tests was set equal to 0.05 .

\section{THE AMERICAN INDUSTRY}

On the 10-point scale, overall, the American projects during the late 1998/early 1999 timeframe scored a 3.86, indicating a relatively low overall level of technology usage.

\subsection{Phase Technology Usage}

Table 1 shows industry-wide phase-level IA Index descriptive statistics for the American industry. Salient observations from these data are offered here.

The American projects employed the most IA technology in the Design and Front-End phases. These phases are information-intensive and, compared to other phases, involve the smallest number of different organizations.

The lowest levels of technology utilization are associated with the on-site phases of Construction Management and Construction Execution. Not surprising, it appears that field organizations are slow in adopting IT technologies.

The differences in technology utilization levels between Phase 1/Phase 2 and Phase 4/Phase 5 of projects are substantial.

Phase 6 of American projects is associated with the greatest overall variability in level of technology employed. While many IT systems exist, many of these are either expensive or complex relative to user skills.

Levels of technology utilization are the most uniform for Phase 5 (Construction Execution) of American projects. Only very few organizations are making significant technological advances in the Construction Execution phase.

\subsection{Work Function Technology Usage}

Table 2 presents the work function-level description statistics for high-tech work functions. For American projects, the highest levels of technology usage pertain to these high-tech work functions. Strong overall trends pertaining to high levels of technology usage include: 1) general dominance of task automation and 2) general dominance of work functions in Design phase.

Table 3 presents the work function-level description statistics for low-tech work functions. The lowest levels of technology used in executing American projects are associated with these low-tech work functions. One strong trend pertaining to low levels of technology usage is the general dominance of work functions in Phase 3, 4, and 5 (Procurement, Construction Management, and Construction Execution).

\section{THE TAIWANESE INDUSTRY}

On the 10-point scale, overall, the Taiwanese projects during the late 2004/early 2005 timeframe scored a 3.90, indicating a relatively low overall level of technology usage.

\subsection{Phase Technology Usage}

Table 4 shows industry-wide phase-level IA Index descriptive statistics for the Taiwanese industry. The Taiwanese projects also employed the most IA technology in the Design and Front-End phases. Similarly, the lowest levels of technology utilization are associated with the on-site phases of Construction Management and Construction Execution. Phase 4 of Taiwanese projects is associated with the greatest overall variability in level of technology employed. Levels of technology utilization are the most uniform for Phase 2 of projects.

\subsection{Work Function Technology Usage}

Table 5 presents the work function-level description statistics for high-tech work functions. For Taiwanese projects, the highest levels of technology usage pertain to these high-tech work functions. Strong overall trends pertaining to high levels of technology usage include: 1) general dominance of task automation and 2) general dominance of work functions in Design phase.

Table 6 presents the work function-level description statistics for low-tech work functions. The lowest levels of technology used in executing Taiwanese projects are associated with these low-tech work functions. One strong trend pertaining to low levels of technology usage is the general dominance of work functions in Phase 3, 4, and 5.

\section{COMPARISONS ACROSS NATIONAL BOUNDARIES}

Project comparison analyses focused on determining if there is a significant difference between Taiwanese projects and American projects in terms of their technology usage. Table 7 shows the technology use index values for the Taiwanese and American industries and the results of the independent-samples $t$ tests. These analyses reveal significant differences in levels of technology usage in the Construction Management between Taiwanese projects and American projects.

\section{CONCLUSIONS}

The purpose of this study was to investigate the extent to which integration/ automation (IA) technologies are being used in executing projects in the Taiwanese and American industries and to quantify the difference of project stakeholders' interest in introducing integration/automation technologies across national boundaries. This was accomplished by two industry-wide surveys and analysis of 209 American projects and 98 Taiwanese projects. Descriptive statistics were developed to determine project-, phase-, and work function-level technology usage. Additionally, hypothesis testing was performed to identify the difference in technology usage between the Taiwanese and American industries.

Specific key findings are recapped as follows:

- Only small differences in IA technology usage exist between Taiwanese projects and American projects.

- Taiwanese and American projects employ the most IA technology in the Design and Frond-End phases. 
The availability of specialized software coupled with limited work scope may help explain the high technology levels associated with these phases.

- All of the "high-tech" work functions are data- or information-intensive, and therefore perhaps more easily automated. Information- and data-intensive work functions appear to be more easily automated than other work function types for Taiwanese and American projects.

- The lowest levels of technology utilization are associated with the on-site phases of Construction Management and Construction Execution in the Taiwanese and American projects.

- Phase 6 (Operations \& Maintenance) of American projects is associated with the greatest overall variability in level of technology employed. Phase 4 (Construction Management) of Taiwanese projects is associated with the greatest overall variability in level of technology employed.

- Levels of technology utilization are the most uniform for Phase 5 (Construction Execution) of American projects. Levels of technology utilization are the most uniform for Phase 2 (Design) of Taiwanese projects.

- For Phase 4, Construction Management, the differences in technology utilization between Taiwanese projects and American projects are significant.

\section{REFERENCES}

[1] O’Connor, J. T., Kumashiro, M. E., Welch, K. A., Hadeed, S. P., Braden, K. E., and Deogaonkar, M. J. (2000). "Project- and phase-level technology use metrics for capital facility projects." Report No.16, Center for Construction Industry Studies, University of Texas, Austin, Tex.

[2] O’Connor, J. T., and Yang, L. (2002). "Capital facility project success and technology usage." Report No.22, Center for Construction Industry Studies, University of Texas, Austin, Tex.

[3] Kumashiro, M.E. (1999). "Measuring automation and integration in the construction industry." MS thesis, University of Texas, Austin, Tex.

[4] Welch, K. A. (1998). "Development of a tool for assessing the degree of automation and integration on capital projects." MS thesis, University of Texas, Austin, Tex.
Table 1: Phase IA Metrics for American Projects

\begin{tabular}{|l|c|c|c|}
\hline \multicolumn{1}{|c|}{ Phase } & N & Mean & Std. Dev. \\
\hline Front-End & 189 & 4.90 & 2.44 \\
\hline Design & 184 & 4.68 & 2.63 \\
\hline Procurement & 199 & 3.46 & 2.42 \\
\hline Construction Management & 198 & 3.27 & 2.15 \\
\hline Construction Execution & 180 & 3.16 & 1.94 \\
\hline Operations \& Maintenance & 152 & 3.67 & 2.64 \\
\hline
\end{tabular}

Table 2: High-Tech WFs for American Projects

\begin{tabular}{|l|c|c|c|}
\hline \multicolumn{1}{|c|}{ Work Function } & N & Mean & Std. Dev. \\
\hline Prepare floor plans & 135 & 6.70 & 3.18 \\
\hline Design electrical systems & 133 & 6.58 & 3.10 \\
\hline Design fluid systems & 104 & 6.39 & 3.15 \\
\hline Design structural systems & 140 & 6.39 & 3.12 \\
\hline Design HVAC systems & 117 & 6.28 & 3.23 \\
\hline
\end{tabular}

Table 3: Low-Tech WF for American Projects

\begin{tabular}{|l|c|c|c|}
\hline \multicolumn{1}{|c|}{ Work Function } & N & Mean & Std. Dev. \\
\hline Fabricate rebar cages & 143 & 1.43 & 2.42 \\
\hline Manipulate/hang sheet rock & 114 & 1.45 & 2.46 \\
\hline $\begin{array}{l}\text { Link field material managers } \\
\text { to suppliers }\end{array}$ & 125 & 1.52 & 2.71 \\
\hline $\begin{array}{l}\text { Plan transport routes } \\
\begin{array}{l}\text { Communicate changes to } \\
\text { field }\end{array}\end{array}$ & 104 & 1.59 & 2.89 \\
\hline
\end{tabular}

Table 4: Phase IA Metrics for Taiwanese Projects

\begin{tabular}{|l|c|c|c|}
\hline \multicolumn{1}{|c|}{ Phase } & N & Mean & Std. Dev. \\
\hline Front-End & 91 & 4.55 & 2.21 \\
\hline Design & 85 & 4.38 & 1.94 \\
\hline Procurement & 88 & 3.96 & 2.13 \\
\hline Construction Management & 93 & 3.74 & 2.44 \\
\hline Construction Execution & 91 & 3.29 & 2.27 \\
\hline Operations \& Maintenance & 78 & 3.84 & 2.36 \\
\hline
\end{tabular}

Table 5: High-Tech WFs for Taiwanese Projects

\begin{tabular}{|l|c|c|c|}
\hline \multicolumn{1}{|c|}{ Work Function } & N & Mean & Std. Dev. \\
\hline $\begin{array}{l}\text { Monitor environmental } \\
\text { impact from operations }\end{array}$ & 58 & 5.09 & 3.17 \\
\hline Prepare floor plans & 70 & 5.07 & 2.48 \\
\hline Prepare milestone schedule & 86 & 4.94 & 3.30 \\
\hline Model user's process & 78 & 4.87 & 2.41 \\
\hline Design structure systems & 77 & 4.87 & 2.69 \\
\hline
\end{tabular}


Table 6: Low-Tech WFs for Taiwanese Projects

\begin{tabular}{|l|c|c|c|}
\hline \multicolumn{1}{|c|}{ Work Function } & N & Mean & Std. Dev. \\
\hline Apply paint/coatings & 76 & 2.83 & 2.62 \\
\hline Finish concrete surfaces & 84 & 2.92 & 2.93 \\
\hline Communication changes to field & 90 & 3.06 & 2.97 \\
\hline Fabricate rebar cages & 75 & 3.07 & 2.71 \\
\hline Pre-operations systems testing & 73 & 3.08 & 2.84 \\
\hline
\end{tabular}

Table 7: $t$-Test for Taiwanese Projects vs. American Projects

\begin{tabular}{|c|c|c|c|c|c|c|c|c|c|}
\hline \multirow[b]{2}{*}{$\begin{array}{c}\text { Technology } \\
\text { Usage } \\
\end{array}$} & \multicolumn{3}{|c|}{$\begin{array}{c}\text { Taiwanese } \\
\text { Projects }\end{array}$} & \multicolumn{3}{|c|}{$\begin{array}{c}\text { American } \\
\text { Projects }\end{array}$} & \multirow[b]{2}{*}{$\begin{array}{l}\text { Mean } \\
\text { Diff. }\end{array}$} & \multirow[b]{2}{*}{$\mathbf{t}$} & \multirow[b]{2}{*}{ Sig. } \\
\hline & $\mathbf{N}$ & $\begin{array}{l}\text { Index } \\
\text { Mean }\end{array}$ & Std. Dev. & $\mathbf{N}$ & $\begin{array}{l}\text { Index } \\
\text { Mean }\end{array}$ & Std. Dev. & & & \\
\hline Project level & 96 & 3.92 & 1.96 & 209 & 3.86 & 1.95 & 0.06 & -- & -- \\
\hline Phase 1 & 91 & 4.55 & 2.21 & 189 & 4.90 & 2.44 & -0.35 & -- & -- \\
\hline Phase 2 & 85 & 4.38 & 1.94 & 184 & 4.68 & 2.63 & -0.30 & -- & -- \\
\hline Phase 3 & 88 & 3.96 & 2.13 & 199 & 3.46 & 2.42 & 0.50 & -- & -- \\
\hline Phase 4 & 93 & 3.74 & 2.44 & 198 & 3.27 & 2.15 & 0.47 & 1.65 & 0.049 \\
\hline Phase 5 & 91 & 3.39 & 2.49 & 180 & 3.16 & 1.94 & 0.23 & -- & -- \\
\hline Phase 6 & 78 & 3.84 & 2.36 & 152 & 3.67 & 2.64 & 0.17 & -- & -- \\
\hline
\end{tabular}

